\title{
OBSERVATIONS ON AFFRICATES IN LIVONIAN
}

\author{
Tuuli Tuisk \\ University of Tartu
}

\begin{abstract}
The aim of the current article is to observe affricates in Livonian. Studies on the Finnic languages have described affricates in South Estonian, Veps, Votic, and Karelian, while Livonian affricates are poorly studied. The phonetic data used in this article show that the voiceless alveolar affricate /ts/ [ [ts], voiceless palatal alveolar affricate /

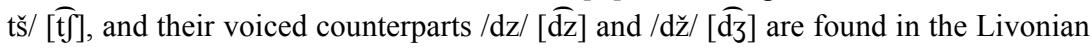

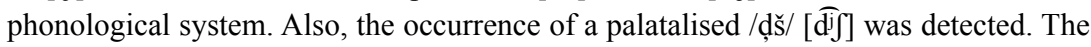
words containing affricates are primarily Latvian loanwords as well as descriptive and onomatopoeic words. There are some acoustic characteristics that differentiate Livonian affricates from consonant clusters. For instance, the duration of affricates is quite short, being sometimes even shorter than that of single fricatives. The transition from the stop to the following fricative in Livonian affricates is not as sharp as in the case of similar consonant clusters. Also, the existence of the broken tone or stød must not be ignored in Livonian, as it can cause changes in the location of the syllable boundary.
\end{abstract}

Keywords: phonology, phonetics, consonants, affricates, Finnic languages, Livonian

DOI: https://doi.org/10.12697/jeful.2018.9.2.09

\section{Introduction}

An affricate can be defined as a sound consisting of a stop ${ }^{1}$ (or closure) and friction in the same place. It is a sequence of a stop followed by a homorganic fricative (e.g., Ladefoged and Johnson 2011). The place of articulation is generally the same for both elements. The most common affricates in the world's languages are the voiceless alveolar $/ \mathrm{ts} / \widetilde{\mathrm{ts}}]$ and palatal alveolar $\left./ \mathrm{ts} / \widetilde{\left[\mathrm{t} \int\right.}\right]^{2}$. Whether the affrication

1 The terms stop, occlusive, and plosive are often used interchangeably. However, some linguists distinguish them and refer to these terms in describing different features of the consonant. Stop refers to the airflow that is stopped; occlusive refers to the articulation, which blocks (occludes) the vocal tract; plosive refers to the release burst (plosion) of the consonant.

2 Corresponding IPA symbols here and henceforth are given in square brackets. In IPA, affricates are represented by two symbols joined by a tie bar [- ]. 
in a particular language is solely a matter of phonetic realisation or plays a phonological role, is a question that can primarily be settled at the phonological level. Equally, there are often phonological reasons in particular languages to analyse phonetic affricates as representing a phonological sequence of a stop and fricative or as two phonologically independent elements (Laver 1994: 365). The present article deals with the affricates of Livonian. The aim of the paper is to describe the phonological and phonetic nature of Livonian affricates.

In describing units of speech at the phonetic level, some degree of air turbulence (friction) at the release of a stop is almost always identified (e.g., Clark, Yallop, and Fletcher 2007, Laver 1995). The release of air normally occurs very rapidly and the moment of release is characterised by a burst of acoustic energy that is only very short-lived. This is usually so short in duration that it counts as part of the release burst of the stop itself. However, there is another phonetic option. When the release is strongly frictional and is extended in duration, it can be identified as a separate fricative phase of the articulation. Such a single complex segment, in which the articulators release an occlusion through a controlled fricative phase, is known as an affricate (Clark, Yallop and Fletcher 2007: 65, Laver 1994: 363-364).

It is often difficult to decide whether a stop (plosive) and fricative form a single affricate sound or a consonant pair. This question depends on whether these components are to be regarded as separate phonemes or not. Therefore, it is difficult to draw a line in classifying affricates. They are rather a middle class between simple plosives and plosivefricative compounds (Ladefoged, Maddieson 1997).

The segmental organisation of languages is not always so easily described. In some cases, a language may actually distinguish between one-segment and two-segment articulation. For example, most English speakers probably regard the initial consonant of chip, chain, chop as a single consonant, even though it consists of a stop and a fricative. Distinguishing between a word-initial affricate and a word-initial sequence of stop + fricative in English is not possible. But in such cases as he cheats vs heat-sheets or what can each add? vs what can eat shad? there is possibly a distinction. Another well-known example from English in which a distinction depends partly on the relative duration of audible friction is in the two cases: between why choose, with a palatoalveolar affricate $[\widehat{\mathrm{t}}]$ ], and white shoes, with a sequence of an alveolar stop [t] followed by a full palato-alveolar fricative [J]. The friction in why choose is relatively short, and the friction in white shoes is relatively long (Clark, Yallop and Fletcher 2007: 70, Laver 1994: 365). 
In cases where some languages have affricates and others may have plosive + fricative sequences, that which appears to be identical in articulation proves not to be valued in the same way in different languages. For instance, the sequence [ts] occurs in English - cats, Dutch - etsen 'to etch', and German - zehn 'ten' or witzig 'funny'. While in English and Dutch this sequence is not an affricate, in German it is normally counted as a single-segment affricate and not simply a sequence of $[t]$ and [s]. Affricates of this type are quite common and are normally represented as single letters within the spelling system of the relevant language, e.g.,

[ts] Polish and Czech $c$ in $c o$ (what) cena (price)

[dz] Italian $z$ in zona (zone) zero (zero)

(Clark, Yallop, and Fletcher 2007: 70)

Ilse Lehiste (1960) compared the consonant cluster and affricate found in the English phrases white shoes vs. why choose. In the first phrase, the consonant cluster occurs at the boundary between two lexical words. In the second phrase, the second word starts with an affricate. Lehiste found (1960: 37-38) that the stop has approximately the same duration in the consonant cluster and also in the affricate. However, the friction has the same duration as the whole affricate itself.

There is a study on the Hungarian affricate /ts/ and consonant cluster /ts/ by Tamas Tarnoczy (1987). He measured the durations of the Hungarian affricates and consonant clusters. According to his measurements, the difference between short and long affricates is an unchanged duration of the fricative and a lengthening of the plosive almost by half of its duration.

\section{The Finnic context of Livonian affricates}

Reconstructions of the Proto-Finnic phoneme system reveal that single affricates and geminate affricates were found in this system. For example, Petri Kallio (2007) has thoroughly described the Proto-Finnic consonants and their changes in history. A general comparison of the Early Proto-Finnic and Late Proto-Finnic consonants shows the tendency of single consonants to decrease in number and geminate consonants to increase. On the basis of changes in the consonant system, there is a possibility to differentiate between the so-called old or early developments and new or late developments. Table 1 shows the ProtoFinnic consonant paradigms. 
Table 1. Early Proto-Finnic and Late Proto-Finnic consonant paradigms (Kallio 2007: 230).

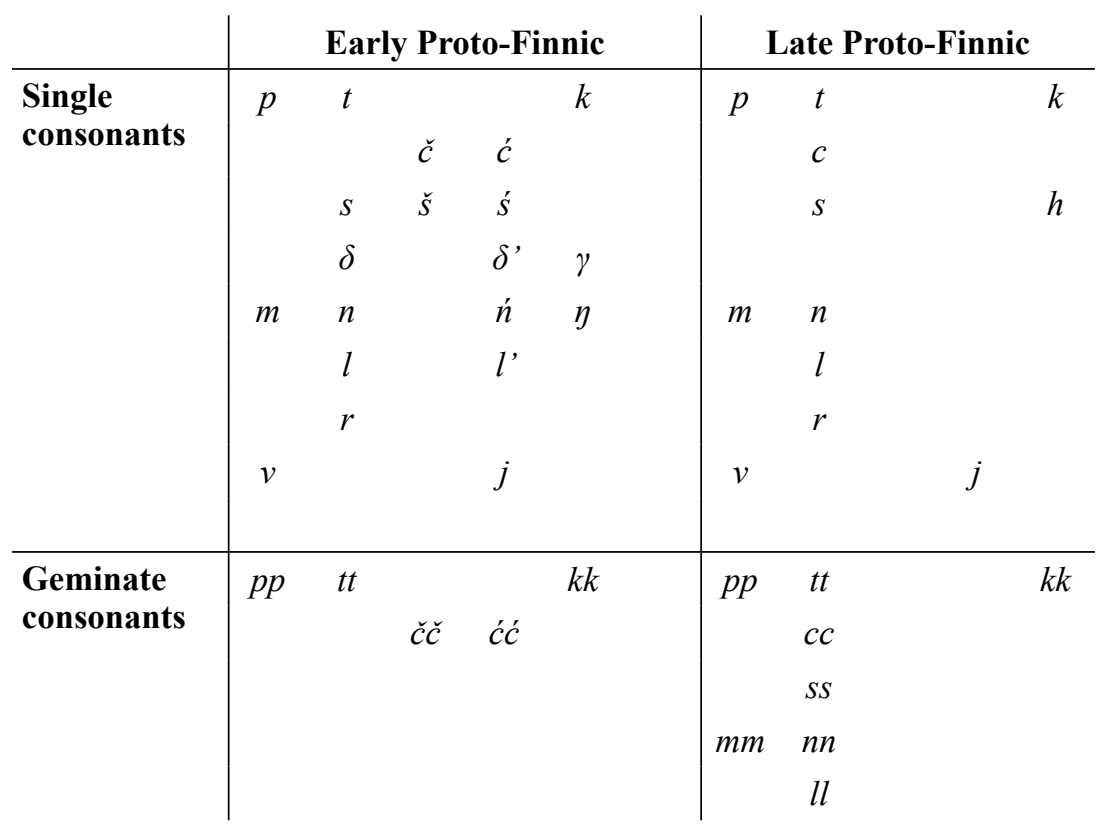

One of the changes that concerns affricates is, for instance, the neutralisation of word-initial $*^{*} \sim *^{\prime} \dot{s}$ and $*^{\prime} \check{c} \sim *^{*}$. The deocclusion of word-initial affricates $*^{\prime} \dot{c}>*^{\prime}$ and $*_{\breve{c}}>*^{\prime}$ was probably the first process that took place. Subsequently, a new word-initial $*^{*} \dot{c}$ and $*^{*} c$ began to appear mostly in descriptive-onomatopoeic words. Also, the elimination of alveolar affricates $* \check{c}>* t$ and $* \check{c} \check{c}>* t \check{s}$ occurred (Kallio 2007).

Affricates are found and generally appear in newer expressive words, loanwords, also in some old words in such Finnic languages as South Estonian (e.g., tsukõldaq 'to bathe'), Karelian (ťškeldoa 'to dive'), Veps (čuklahtada 'to dive'), and Votic (tšülä 'village'). In South Estonian, affricates are found also in old vocabulary, e.g., in such words as hüdsi 'coal', kö̈ds' 'rope'.

Affricates are well represented in Votic (Ariste 1948: 14-15). The voiceless palatal affricate / $/ \mathrm{s} /$ is very common in Votic, appearing in such words as tšäsi 'hand', kurtši 'stork', etc. Votic has been in contact with Russian, but the Votic affricate is less palatalised and is pronounced further back than Russian $u$. The affricate /ťs/ has a voiced equivalent / dž/, which is found mostly in Eastern Votic, for example, redžed 'sled', audžid 'pikes'. Paul Ariste includes voiceless /štš/ (Russian щ, e.g., 
štšetina 'bristle'), found in Russian loanwords, and voiceless alveodental /ts/ (kutsun 'I call, I invite') in the list of Votic affricates. Affricates take part in quantity alternation, e.g., pittšä 'long, NSg' : pitš̋̈ 'long, GSg'.

Tiit-Rein Viitso has analysed Veps affricates in his study on the phonology of the Finnic languages (Viitso 1981, supplemented version in Viitso 2008). In Veps, there are the word-initial affricates $t \check{s} \sim \check{c}$, wordmedial $t s \sim c, t s \dot{s} \sim \dot{c}, t \check{s} \sim \check{c}, d \check{z} \sim \check{\zeta}$, and word-final $t s \sim c, t \check{s} \sim \check{c}$. The main problem with these affricates is whether they represent single phonemes (affricates) or phoneme compounds. There are morphological arguments concerning $t \check{s}$, and the situations where it should be considered a phoneme compound. For instance, the word veit $\bar{s}^{\prime} \sim v \bar{t} t \grave{s}$ ' $\mathrm{knife}$ ' declines as veitš $(\mathrm{NSg})$ : veitšen $(\mathrm{GSg})$ : vešt $(<*$ *veist) $(\mathrm{PSg})$ : veitšhe $(\mathrm{IllSg})$. The loss of the plosive appears in the partitive case. However, there are also arguments in favour of its analysis as a single phoneme. For example, Veps is strongly influenced by the Russian language and in Russian there are the affricates /c/ and /č/. Also, the speaker's intuition should be considered. Affricates in North Veps are written in Cyrillic as $u$ and $u$, but not as the combination of letters $m c$ and $m u$ (Viitso 2008: 214-215).

In Estonian, the presence or absence of affricates has been a much debated issue. There are different views with respect to this topic. Paul Ariste (1953: 51-53) has considered the consonant clusters /ts/, /tš/,/dž/ to be affricates, i.e., sequences of a plosive and homorganic fricative. However, Mati Hint (1998: 136) suggests that there is no reason to talk about affricates in the Estonian literary language, as the /ts/ sequence behaves much the same as the $/ \mathrm{ks} /$ and $/ \mathrm{ps} /$ sequences. It is rather impossible to consider $/ \mathrm{ks} /$ and $/ \mathrm{ps} /$ as single sounds in Estonian, so the /ts/ sequence should be treated as a consonant cluster instead.

On the basis of morphological and phonological studies, it is certain that affricates are present in South Estonian dialects. Salme Nigol has given a thorough overview of affricates in the Hargla dialect (e.g., Nigol 1957, Nigol 1994). Mati Hint has described the phonetic and phonological system of the Rõuge dialect (Hint 1965). He notes that affricates occurs in all three quantities and in the most important positions where plosives and /s/ appear. He proposes that the South Estonian affricate / ts/ cannot be considered a consonant compound, because of the threeway quantity opposition. He finds it especially important to note that affricates appear in the codas of over-long syllables (e.g., köids 'rope'). Still, Hint finds that the phonological affricate causes certain difficulties 
both in the phonological and morphological system. The reasons for that are the absence of /ts/ sequences in the phonological system and the loss of the morphemic boundary in the case of the affricate (for instance, the word leidmä 's/he finds' - leidse 's/he found') (Hint 141-142).

Pärtel Lippus (2005) studied the durations of the affricate/ts/ [ [ts] in Vorru South Estonian and compared the results with Standard Estonian / ts/. His acoustic analysis confirmed that the affricate /ts/ [ [ts] in Võru differs from the consonant cluster/ts/ in Standard Estonian. The analysis of the materials from Voru and Standard Estonian speakers showed that in the position with a quantity opposition, there is a ternary opposition for the affricate/ts/ [ ts] in Vorru. There is definitely an affricate in Q1 words the Võru dialect as a consonant cluster is not possible in this context.

One of the major sound laws from Proto-Finnic to Proto-Livonian is the deocclusion $*_{c}>*_{s}$ (Kallio 2016: 40-41). This elimination is common to all of Finnic with South Estonian being the only exception, e.g., *cika $>*$ sika (> Courland Livonian sigā, Salaca Livonian šiga) 'pig', *süci > *süsi (> Courland Livonian si'ž, Salaca Livonian šius) 'charcoal'. There are two exceptions to this elimination. The first one is the development $* c k>* t k$, common to all Finnic languages with the exception of South Estonian, e.g., *kocka $>* k o t k a-(>$ Courland Livonian kuotkānõz, Salaca Livonian kotkas) 'eagle' (Kallio 2016: 40). The distribution of the second development $* c r>* t r$ is rather unusual. It covers Livonian, South Estonian, most of North Estonian, Votic, and East Finnish, e.g., *kecrä $>*^{*}$ keträ (> Courland Livonian kie'ddorr) 'spindle', *ocra $>*$ otra (> Courland Livonian vó'ddõrz, Salaca Livonian odr) 'barley' (Kallio 2016: 41). The elimination of the phoneme ${ }^{*} c$ as a result of this change gave a chance to phonologically re-analyse the geminate $* c c$ as the cluster $* t s$. Thus, the old Finnic affricates disappeared from the Livonian language. Probably due to contacts with neighbouring languages, foremost with Latvian, at some point affricates began to develop again. In Livonian, affricates appear mostly in loanwords, descriptive and onomatopoeic words, but also in some native words.

\section{Affricates in Livonian}

There are 23 consonant phonemes (excluding affricates) in contemporary Livonian: /b, d, d, g, p, t, ț, k, f, v, h, j, l, l, m, n, n, , r, r, z, s, ž, ̌s/ (see Table 2). 
Table 2. Livonian consonants.

\begin{tabular}{|c|c|c|c|c|c|c|c|c|}
\hline & Bilabial & $\begin{array}{l}\text { Labio- } \\
\text { dental }\end{array}$ & $\begin{array}{l}\text { Alveo- } \\
\text { lar }\end{array}$ & $\begin{array}{l}\text { Post- } \\
\text { alveolar }\end{array}$ & $\begin{array}{l}\text { Palat- } \\
\text { alised }\end{array}$ & $\begin{array}{c}\text { Pala- } \\
\text { tal }\end{array}$ & Velar & $\begin{array}{c}\text { Glot- } \\
\text { tal }\end{array}$ \\
\hline Plosive & $\mathbf{p} \mathbf{b}[\mathrm{p} b]$ & & $\mathbf{t} \mathbf{d}[\mathrm{td}]$ & & $\mathbf{t} \mathbf{d} \mathbf{d}\left[\mathrm{t}^{\mathrm{j}} \mathrm{d}^{\mathrm{j}}\right]$ & & $\mathbf{k} \mathbf{g}[\mathrm{k} \mathrm{g}]$ & \\
\hline Nasal & $\mathbf{m}[\mathrm{m}]$ & & $\mathbf{n}[\mathrm{n}]$ & & n $\left[n^{\mathrm{j}}\right]$ & & & \\
\hline Trill & & & $\mathbf{r}[\mathrm{r}]$ & & $\mathbf{r}\left[\mathrm{r}^{\mathrm{j}}\right]$ & & & \\
\hline Fricative & & $\mathbf{f} \mathbf{v}[\mathrm{f} v]$ & $\mathbf{s} \mathbf{z}[\mathrm{s} z]$ & \multicolumn{2}{|c|}{$\check{\mathbf{s}} \check{\mathbf{z}}\left[\int 3 \int^{\mathrm{j}} 3^{j}\right]$} & & & $\mathbf{h}[\mathrm{h}]$ \\
\hline Lateral & & & $\mathbf{I}[1]$ & & $\mathbf{l}\left[\mathrm{ll}^{\mathrm{j}}\right]$ & & & \\
\hline $\begin{array}{l}\text { Approxi- } \\
\text { mant }\end{array}$ & & & & & & $\mathbf{j}[\mathrm{j}]$ & & \\
\hline
\end{tabular}

The Livonian plosive $\mathbf{t}$ is pronounced as a voiceless consonant, being similar to the corresponding plosive in Estonian and Latvian. The short plosive $\mathbf{d}$ is voiced word-initially and in voiced position (e.g., sada 'hundred'). In front of $s$ and in word-final position, $\mathbf{d}$ is weak and voiceless (or half-voiced) (e.g., la 'gtõ 'to lay out', ke'g 'cuckoo'). The voiceless fricative $\mathbf{s}$ is similar to Estonian and Latvian $s$ (e.g., sova ' 'stick'). The alveolar fricative $\mathbf{z}$ is fully voiced word-initially and in voiced position (e.g., zup 'soup', iz $\bar{a}$ 'father'). The fricative š is voiceless (e.g., sirts 'apron'). The fricative $\check{\mathbf{z}}$ is fully voiced in word-initial and voiced position (e.g., $a \check{z} \bar{a}$ 'thing'). Word-final $\mathbf{z}$ and $\check{\mathbf{z}}$ can sometimes become half-voiced or unvoiced.

In the Livonian phonological system, generally four affricates are found: /ts/ [ [ts] and /ťs/ $[\widehat{\mathrm{t}}]$ and their voiced counterparts /dz/ $[\widehat{\mathrm{dz}}]$ and /

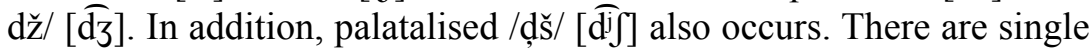
affricates and affricates that are part of consonant clusters (e.g., $t \check{s} a b \bar{a}$ 'a fool', järāndz 'away').

The presence of affricates in Livonian is quite a new phenomenon and is generally connected to loanwords and descriptive-onomatopoeic words. For instance, Lauri Posti (1942: 139) notes that word-initial voiceless affricates /ts/ and /ťš in Livonian are found in either Latvian or German loanwords and descriptive words. But the nature of an affricate cannot always be unambiguously described. For instance, Posti indicates that there are words such as $t s i l$ [tsili ${ }^{\mathrm{j}}$ 'hedgehog' (in Posti's transcription $t s \bar{l} l(\sim s \bar{l})$, est siil, lv ezis) where the combination /ts/ should not be treated as an affricate, as originally this used to be $\dot{s}$ (Posti 1942: 139). 
Livonian affricates clearly have many equivalents in Latvian. The inventory of consonant phonemes of Standard Latvian distinguishes

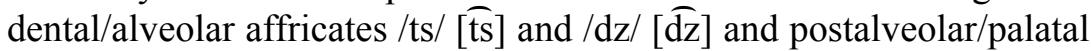

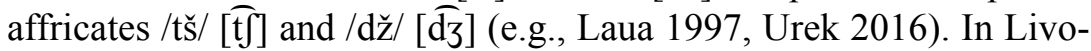
nian, affricates are represented as two letters within the spelling system, while in Latvian, /ts/ and /tš/ are represented as the single letters /c/ and $/ \check{c} /$.

Affricates are characteristic also of Salaca Livonian, spoken within the territory of historical Livonia (Pajusalu 2011: 224, Winkler and Pajusalu 2018: 51-61). In Salaca Livonian, five types of affricates are observed: $c[\widehat{\mathrm{ts}}], c \dot{c}[\widehat{\mathrm{ts}}], \check{c}[\widehat{\mathrm{t}}], 3[\widehat{\mathrm{dz}}]$ and $\breve{\zeta}[\widehat{\mathrm{d}}]$.

(1) $c[\widehat{\mathrm{ts}}]$ occurs word-initially in such words like tsirlingki 'lark', word-medially mytsa 'wood', word-finally jäets jääts 'in front of, before'.

(2) $\dot{c}\left[\widehat{\mathrm{ts}}^{\mathrm{j}}\right]$ occurs word-finally, for instance in klāntsj 'bag; pocket'.

(3) $\check{c}[\widetilde{\mathrm{t}}]$ appears word-initially in tsaun $\sim$ tšaun 'marten' (est nugis, lv cauna), also as the first part of the consonant cluster kutški 'puppy', word-finally otš 'look for, ImpSg2'.

(4) 3 [ $\widehat{\mathrm{dz}}]$ word-initially $d z e r u l$ ' 'cranberry' (est jõhvikas, lt dzervene), word-medially säedzed 'pretty, NPl', word-finally kuods ( kuod) 'court'.

(5) $\check{3}[\widehat{\mathrm{d}}]$ džuokžed 'gums'.

In Livonian literary sources (see Damberg 1978a, 1978b, Ernštreits 2013 for details), the marking of affricates was evident already in the 19th century. For example, in the Gospel of Matthew (1880), Gothic letters were used and the orthography corresponds to the Latvian spelling system at that time. In marking affricates and fricatives, the old Latvian spelling system is used (wot/schuhb $=$ votš $\bar{u} b$ 'he or she seeks', wihfch maizõnt = vizz ma 'itsõnt 'five pounds').

In the 1920s and 1930s, the discussions concerning the creation of a Livonian orthography were very active. There were attempts to use the dialect of İra village as the basis for the Livonian spelling system. In 1932 and 1933, following the suggestion of Mart Lepste and Laimonis Rudzitis, two Livonian calendars were published using the İra dialect. The letters $c$ and $\check{c}$ were added to the alphabet to mark $t s$ and $t \check{s}$, e.g., mic 'how many?', neicod 'girls', voččo 'to seek'. However, this innovation seems a little unreasonable, as the syllable boundary is in the middle of /ts/ and /tš/ (for instance, in mõca 'forest' : mõcco 'forest, PSg, IllSg'). 
$c$ and $\check{c}$ are written mostly in cases where there are morphological alternations and not just where they occur phonetically, e.g., jieds 'in front of, before' but not jiec. However, on some occasions /c/ and /č/ are used anyway, e.g., äc kuskis 'somewhere' (ädskuskis, est kusagil), kȳńčrōda 'ploughshare' (kindžrōda, est adrahõlm).

\section{Materials and method}

The purpose of the current paper is to describe Livonian affricates and provide some acoustic data. This research study does not attempt to be a comprehensive phonological or phonetic study with a large amount of data. The focus here is mostly on single affricates, as this is a good starting point for the further study of affricates as part of consonant clusters. Also, the study of the palatalisation of affricates remains a topic for future research. All the spectrogram examples presented in the discussion show single affricates.

The sources of the word examples in the current paper are the Livonian-Estonian-Latvian dictionary (Viitso and Ernštreits 2012, the online version has been available since 2013) and the Livonian dictionary (Kettunen 1938). Examples use the Standard Livonian orthography with the IPA ${ }^{3}$ equivalent is given in square brackets. For acoustic data, old Livonian recordings from the AEDKL ${ }^{4}$ were studied. The test words were segmented using the Praat software package (version 6.0.43). Test words were collected from two native Courland Livonian speakers. The female speaker EŽ (born in 1914) was recorded in 1997. The male speaker PD (born in 1909) was recorded in 1986. Both speakers are from Sīkrõg village, which belongs to the Eastern Livonian dialect area.

The acoustic data come from controlled speech, in which test words occurred in sentence-initial (SI), phrase-initial (PI), phrase-medial (PM), phrase-final (PF), and sentence-final (SF) position. In the tables, all the segment durations are presented. The durations of the segments in focus are highlighted. For each affricate, the durations of the closure (or stopstage, occlusion) and the following frication are given together with the entire affricate duration. In the analysis of the acoustic examples, the

$3 \quad$ IPA = International Phonetic Alphabet

4 AEDKL $=$ University of Tartu Archives of Estonian Dialects and Kindred Languages 
durations of the sequences and segments as well as the transition from the stop to the following fricative are in focus.

\section{Discussion}

In the following sections, four main types of Livonian affricates

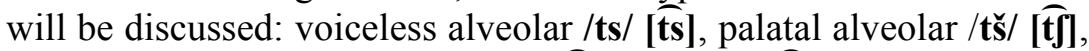
and their voiced counterparts $/ \mathbf{d z} /[\hat{\mathbf{d} z}]$ and $/ \mathbf{d} \check{\mathbf{z}} /[\widehat{\mathbf{d}}]$ ]. These affricates occur in word-initial, word-medial, and word-final position and are most evident in loanwords, especially in Latvian loanwords as well as descriptive and onomatopoeic words. In the current analysis, the focus is generally on single affricates. In addition, comments on voiced /ds/

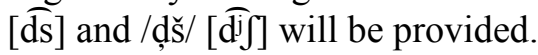

Most problematic is the occurrence of voiceless /ts/ and /tšs in wordmedial position between vowels and whether in this position they should be interpreted as geminate affricates or as sequences of consonants.

\subsection{Word-initial affricates}

The voiceless affricates $/ \mathbf{t s} /[\widehat{\mathbf{t s}}], / \mathbf{t} \check{\mathbf{s}} /[\widehat{\mathbf{t}}]$ ] and the voiced affricates $/ \mathbf{d z} /[\widehat{\mathbf{d z}}]$ and $/ \mathbf{d} \mathbf{z} / / \widehat{\mathbf{d}} \mathbf{z}]$ can appear in word-initial position in Livonian. In word-initial position, only single affricates are possible. Words starting with voiceless $/ \mathrm{ts} /$ and $/ \mathrm{ts} /$ are better represented in Livonian than words starting with their voiced counterparts.

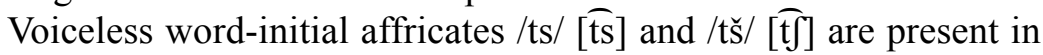
Latvian and German loanwords as well as in descriptive and onomatopoeic words, e.g.,

tsak [tsaklimi] 'cusp' (de Zacke, est sakk, lv robs)

tseplā [tseplia'] 'oven, stove' (est ahi, põletusahi, lv ceplis)

tšsirlinki [t $\mathrm{ti}:$ :rlinki] 'lark' (est lõoke, lv cìrulis)

tš̌lk-tššlk [t fii:k-t $\mathrm{fi}: \mathrm{k}]$ 'the sound a mouse makes' (est piiks-piiks, lv čiep

čiep, $\check{c} \bar{l} \bar{c} c \bar{l})$

tšūǔõ [tfu::zə] 'to whisper' (est sosistada, lv čukstēt)

tšärrks [t $\lceil æ r:: k s]$ 'the sound of something coming apart at the seams' (est

kärr, lv kraukš)

tšoļk [t folik] 'slop' (est solk, solgivesi, lv samazgas)

tšoškõ [t $\mathrm{fo} \mathrm{J} \mathrm{k}$ ] 'to prod' (est susata, lv iebakstit), etc. 
In the following examples, a comparison of word-initial /ts/ and a word-initial single fricative is presented. In Figure 1, the spectrogram of the place name Tsälmõt [tsælmət] 'Tsälmõt (river)' (est Tsälmõti jõgi, lv Celmupe) is shown. The corresponding segment durations are given in Table 3. In Figure 2 and Table 4, the spectrogram and the segment durations of the word seiskimdõ 'seventy' (est seitsekümmend, lv septindesmit) are shown.
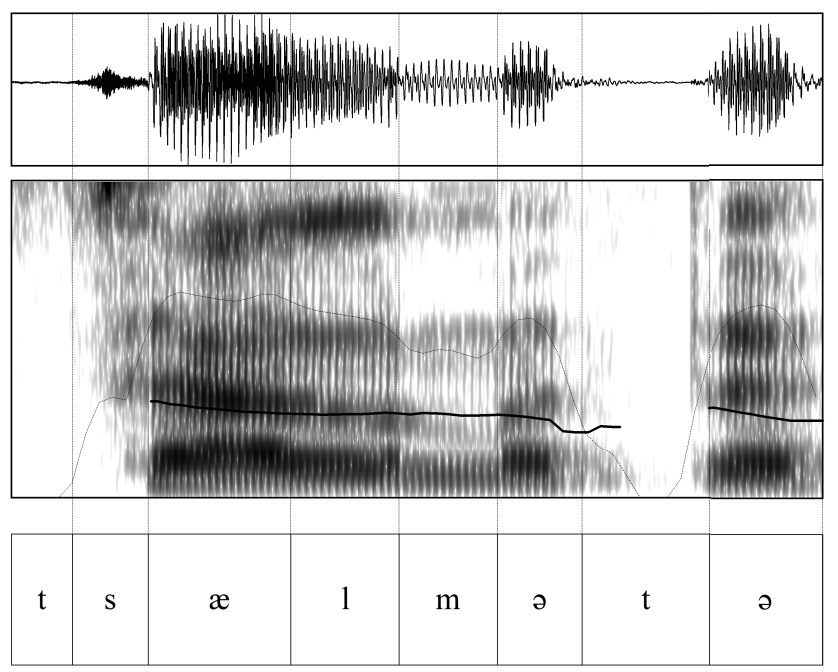

Figure 1. Spectrogram of the sentence-final test word Tsälmõtõ 'Tsälmõt, IllSg' (pronounced by male speaker PD).

Table 3. Segment durations (in ms) of the word Tsälmõtõ 'Tsälmõt, IllSg' (SF = sentence-final position, pronounced by male speaker PD).

\begin{tabular}{c|c|c|c|c|c|c|c|c|c} 
& $\mathbf{C 1} / \mathbf{t} /$ & $\mathbf{C 2} / \mathbf{s} /$ & $\mathbf{V 1}$ & $\mathbf{C 3}$ & $\mathbf{C 3}$ & $\mathbf{V 2}$ & $\mathbf{C 4}$ & $\mathbf{V 3}$ & $/ \mathbf{t s} /$ \\
\hline $\mathbf{S F}$ & 61 & 74 & 140 & 108 & 97 & 83 & 125 & 112 & 135 \\
\end{tabular}



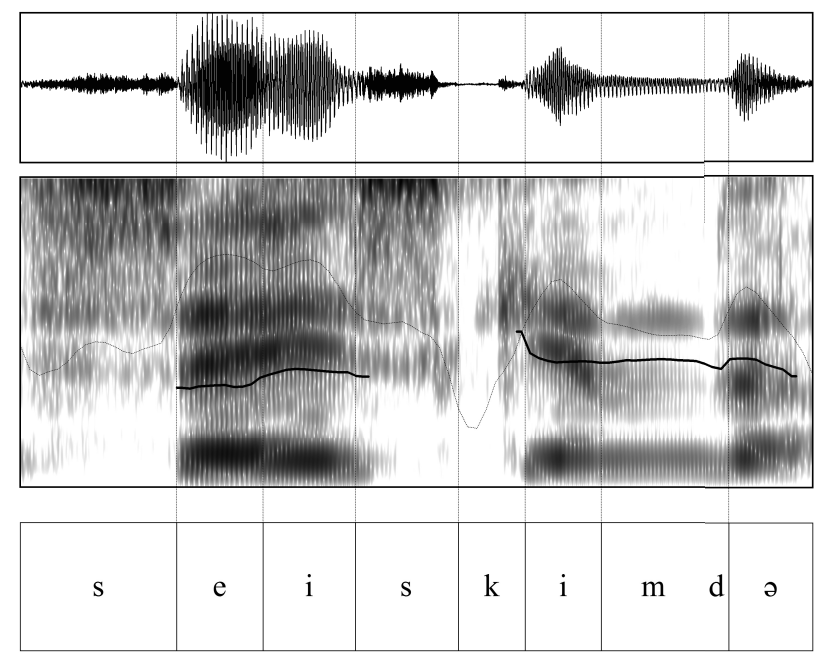

Figure 2. Spectrogram of the phrase-medial test word seiskimdo 'seventy' (pronounced by male speaker PD).

Table 4. Segment durations (in ms) of the word seiskimdõ 'seventy' $(\mathrm{SF}=$ sentence-final position, pronounced by male speaker $\mathrm{PD})$.

\begin{tabular}{c|c|c|c|c|c|c|c|c|c} 
& $\mathbf{C 1} / \mathbf{s} /$ & $\mathbf{V 1}$ & $\mathbf{V 2}$ & $\mathbf{C 2}$ & $\mathbf{C 3}$ & $\mathbf{V 3}$ & $\mathbf{C 4}$ & $\mathbf{C 5}$ & $\mathbf{V 4}$ \\
\hline $\mathbf{P F}$ & 191 & 106 & 113 & 128 & 82 & 93 & 128 & 30 & 102
\end{tabular}

There is a remarkable duration difference between the word-initial affricate and word-initial single fricative, $135 \mathrm{~ms}$ vs. $191 \mathrm{~ms}$. The closure and the frication in the affricate are also rather short in duration.

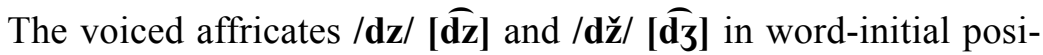
tion are considerably less represented in Livonian. They occur in similar word types as voiceless word-initial affricates, i.e., in Latvian loanwords as well as descriptive and onomatopoeic words. These affricates are generally followed by the high vowels $i$ or $u$, for example in the words

$d z \grave{\imath}$ ’ksõl [dzi::'ksəl] 'vein' (est soon, lv dzīsla)

$d z i n$, $d z i n$ [ [dzin' dzin'] 'the whining sound mosquitoes make' (est pinnpinn, lt dzin dzin)

$d \check{z}$ indž̃ $[\mathrm{d} z$ indzə] 'to make the whining sound of mosquitoes' (est piniseda, lv džinkstēt)

džutškõ [dzukstə] 'to prod' (est susata, lv bakstīt) 
Unfortunately, there were no acoustic data found consisting of voiced word-initial affricates.

\subsection{Word-medial affricates}

The following word-medial voiceless geminate affricates are found

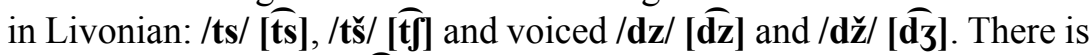
also a palatalised /d̦ $/ \mathbf{s} /[\widehat{\mathbf{d}} \mathbf{j}]$ in Livonian. Affricates are found in various nouns, verbs, adverbs, and loanwords, e.g., brutsinntõ 'to rub' (est nühkida, lv berzt), butšintntõ 'to smooch' (est musitada, lv bučot). Occasionally, affricates can also be part of a consonant cluster, e.g., in such words as āldža 'sneeze' (est aevastus, lv šksavas), indzi 'enthusiastic' (est innukas, lv centīgs), etc. The occurrence of palatalised /d̦š/ between vowels and as a part of consonant clusters should also be noted, for example,

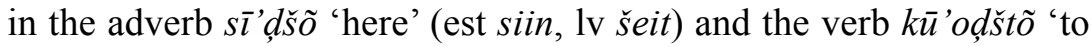
litigate' (est kohut käia, lv tiesāties).

Single voiceless plosives cannot appear between vowels in Livonian. Also, voiceless /ts/ $[\widetilde{\mathbf{t s}}]$ and $/ \mathbf{t} \check{\mathbf{s}} /[\widehat{\mathbf{t}}]]$ are not single affricates in this position but geminate affricates. For instance, in words such as $m \tilde{o} t s \bar{a}$ 'forest, NSg' and mõtsõ 'forest, PSg, IllSg', there are short and long geminates, respectively. It should be noted that mõts $\bar{a}$ shows quantity alternation. According to the Livonian quantity system, the word $m \tilde{o} t s \bar{a}$ is in the weak grade and mõtsõ in the strong grade ${ }^{5}$. mõts $\bar{a}$ and $m \tilde{o} t s \tilde{o}$ behave similarly to words such as võtāb 's/he takes' and võttõ 'to take, Inf' and katāb 's/he covers' and kattõ 'to cover'. In the following spectrograms, the words $m \tilde{o} t s \bar{a}$ [mutsa'] 'forest' and mõtsõ [mut:sə] 'forest, PSg, IllSg' are presented (Figure 3). In Table 5, the respective segment durations are given.

5 For details on Livonian quantity see, for example, Viitso 2007, Lehiste et al. 2008. 


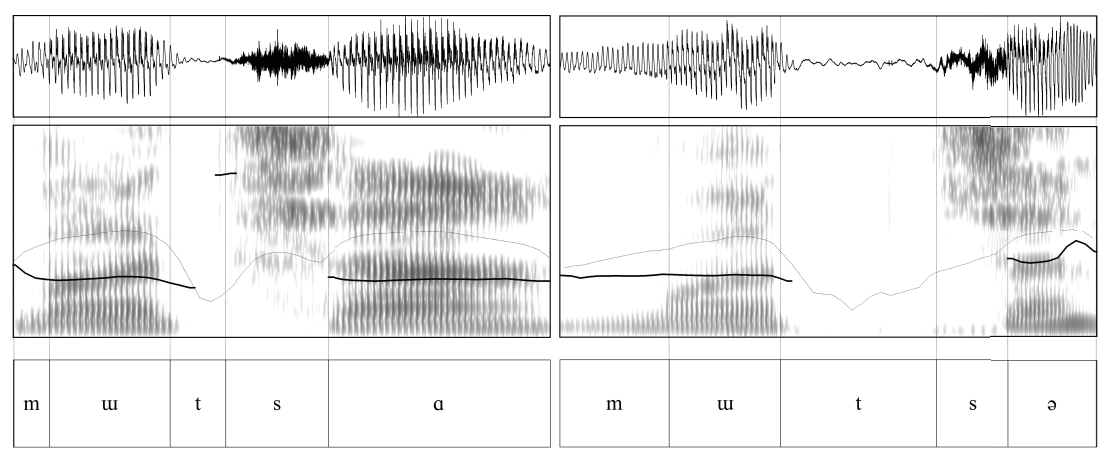

Figure 3. Spectrograms of the sentence-final test word mõts $\bar{a}$ 'forest' (on the left) and the phrase-final mõtsõ 'forest, PSg, IllSg' (on the right) (pronounced by female speaker EŽ).

Table 5. Segment durations (in ms) of the sentence-final test word $m \tilde{t} t s \bar{a}$ 'forest' and phrase-final mõtso 'forest, PSg, IllSg' (SF = sentence-final position, $\mathrm{PF}=$ phrase-final position, pronounced by female speaker EŽ).

\begin{tabular}{c|c|c|c|c|c|c} 
& $\mathbf{C 1}$ & $\mathbf{V 1}$ & $\mathbf{C 2} / \mathbf{t} /$ & $\mathbf{C 3} / \mathbf{s} /$ & $\mathbf{V 2}$ & /ts/ \\
\hline $\mathbf{S F}$ & 43 & 147 & $\mathbf{6 8}$ & $\mathbf{1 2 5}$ & 271 & $\mathbf{1 9 3}$ \\
\hline $\mathbf{P F}$ & 151 & 157 & $\mathbf{2 1 6}$ & $\mathbf{1 0 0}$ & 121 & $\mathbf{3 1 6}$
\end{tabular}

Pärtel Lippus (2005) has analysed the South Estonian Võru affricate /ts/ and Standard Estonian consonant cluster/ts/. An important difference between the Võru affricate and Standard Estonian consonant cluster can be seen in the duration ratios between the closure and frication component (Lippus 2005: 71-76). If the closure and frication component do not take part in the quantity alternation (i.e., in word-initial and word-final position), the duration of both components of the affricate is similar. In Standard Estonian, the duration of the frication remains stable, but the closure duration is lengthened. When there is a quantity alternation, both components in the affricate generally are lengthened in Võru. In Standard Estonian consonant clusters, the frication duration remains unchanged and the duration of the stop is lengthened. In the case of Livonian mots $\bar{a}$, the duration of the fricative is considerably longer than that of the stop and in mõtsõ the situation is just the opposite, the duration of the stop is twice as long as that of the fricative. The 
current measurement results would suggest that there are short and long geminate affricates in these words. However, for a better explanation it is necessary to compare this type of affricate to those in Latvian in future studies. It appears that Livonian /ts/ does not behave in the same manner as the corresponding affricate in South Estonian and Standard Estonian.

Figure 4 and Table 6 show the example word mõtsākaits [mutsa kaits] 'forest ranger'.

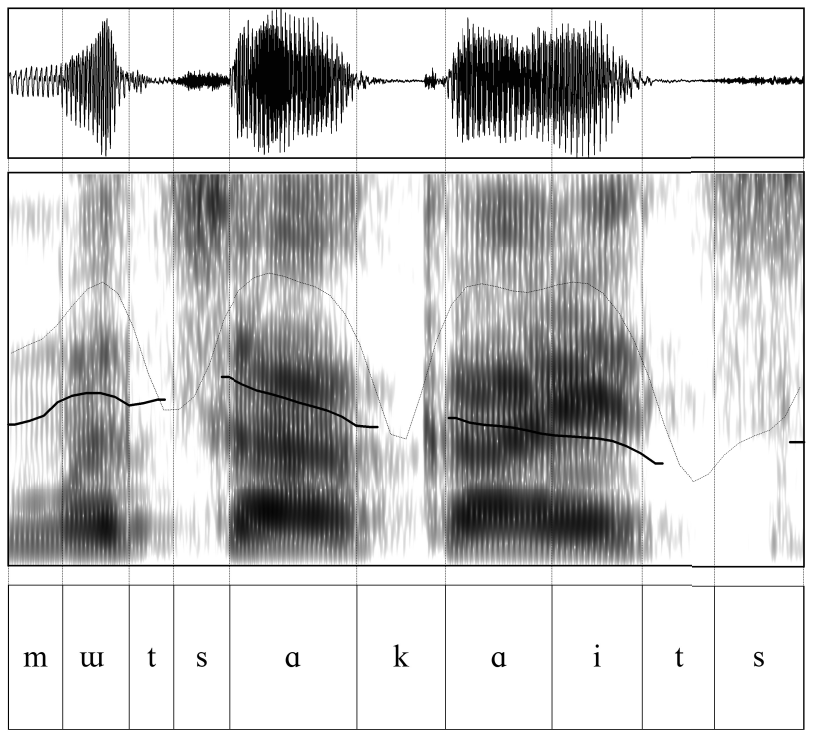

Figure 4. Spectrogram of the phrase-medial test word mõtsākaits 'forest ranger' (pronounced by male speaker PD).

Table 6. Segment durations (in ms) of the word mõtsākaits 'forest ranger' $(\mathrm{PM}=$ phrase-medial position, pronounced by male speaker PD).

\begin{tabular}{c|c|c|c|c|c|c|c|c|c|c|c|c|} 
& $\mathbf{C 1}$ & $\mathbf{V 1}$ & $\mathbf{C 2} / \mathbf{t} /$ & $\mathbf{C 3} / \mathbf{s} /$ & $/ \mathbf{t s} /$ & $\mathbf{V 2}$ & $\mathbf{C 4}$ & $\mathbf{V 3}$ & $\mathbf{V 4}$ & $\mathbf{C 6} / \mathbf{t} /$ & $\mathbf{C 7} / \mathbf{s} /$ & $/ \mathbf{t s} /$ \\
\hline $\mathbf{P M}$ & 57 & 70 & $\mathbf{4 7}$ & $\mathbf{5 9}$ & $\mathbf{1 0 6}$ & 135 & 93 & 112 & 95 & $\mathbf{7 7}$ & $\mathbf{9 3}$ & $\mathbf{1 7 0}$ \\
\end{tabular}

This word is also a good example of short and long geminate affricates in Livonian. The intervocalic word-medial /ts/ can be interpreted as a short voiceless geminate affricate and the word-final/ts/ as a long 
voiceless affricate. The transition from closure to frication is sharper in the short geminate affricate and smoother in the long geminate affricate.

A case similar to the situation observed in mõts $\bar{a}$ and mõtsõ, but with a word-medial voiceless / $/ \mathrm{s} /$ sequence, can be seen in the following example. In Figure 5 and Table 7, the spectrogram and segment durations of the word vitš̄u $b$ [vrtfu'b] 's/he seeks' are shown.
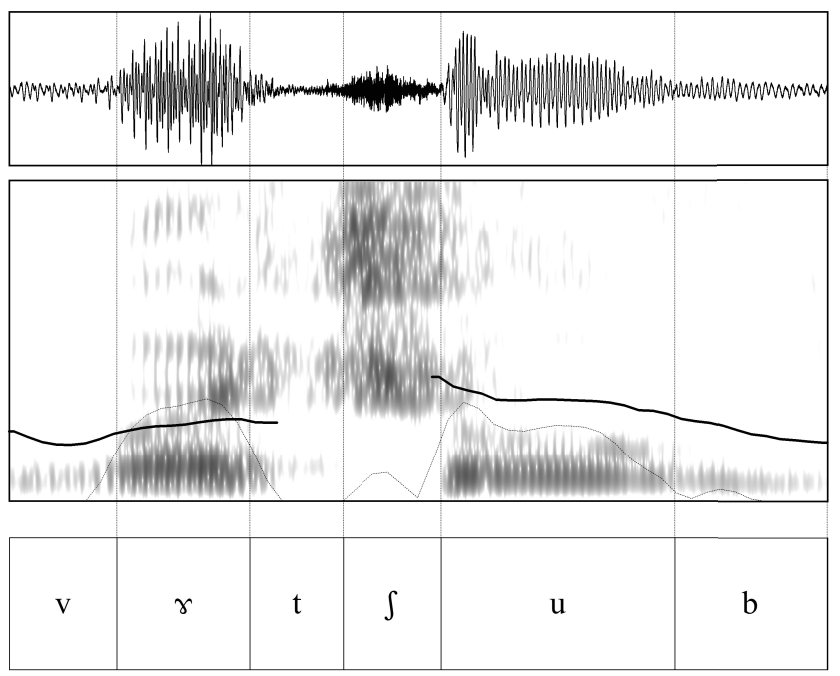

Figure 5. Spectrogram of the phrase-medial test word vötšūb 's/ he seeks' (pronounced by male speaker PD).

Table 7. Segment durations (in ms) of the word votšn̄ 's s/he seeks' ( $\mathrm{PM}=$ phrase-medial position).

\begin{tabular}{c|c|c|c|c|c|c|c} 
& $\mathbf{C 1}$ & $\mathbf{V 1}$ & $\mathbf{C 2} / \mathbf{t} /$ & $\mathbf{C 3} / \check{\mathbf{s}} /$ & $\mathbf{V 2}$ & $\mathbf{C 4}$ & $/ \mathbf{t} \check{\mathbf{s}} /$ \\
\hline $\mathbf{P M}$ & 82 & 100 & 71 & 74 & 176 & 115 & 145
\end{tabular}

The durations of the segments in the /tšs/ sequence are almost the same. This word also shows quantity alternation. According to the Livonian quantity system, the word vot $t^{5} \bar{u} b$ is in the weak grade and vot $s^{5} \tilde{o}$ 'to seek, Inf' is in the strong grade. The plosive /t/ is slightly palatalised here. The durations of the closure and the subsequent frication in $/ \mathrm{ts} /$ in the word $v \dot{o} t s \bar{u} b$ are short. Therefore, the /tš/ in this example can be considered to be a short geminate affricate. 
There are words in Livonian in which one finds /ds/ between vowels when written in the standard orthography. Some of these words are, for example, nouns and adverbs that are pronounced with the broken tone or

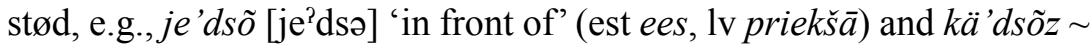

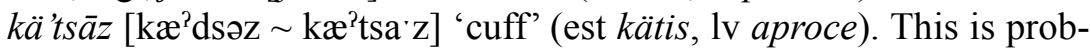
ably an allophone of the affricate /dz/ and should not be considered an independent affricate. Figure 6 and Table 8 show the spectrogram and segment durations of the word lä́' $d s \tilde{o}$ 'to go, Ger'.
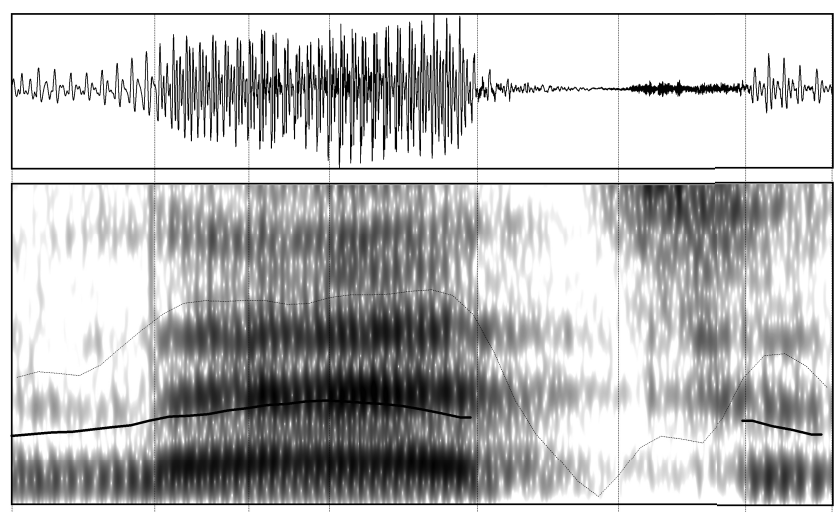

\begin{tabular}{|l|l|l|l|l|l|l|}
\hline 1 & $\mathfrak{x}$ & $\mathrm{P}$ & $\mathfrak{1}$ & $\mathrm{d}$ & $\mathrm{s}$ & ə \\
\hline
\end{tabular}

Figure 6. Spectrogram of the sentence-initial test word $l \bar{a}$ ' $d s \tilde{o}$ 'to go, Ger' (pronounced by male speaker PD).

Table 8. Segment durations (in ms) of the word lä ' $d s \tilde{o}$ 'to go, Ger' (SI = sentence-initial position).

\begin{tabular}{c|c|c|c|c|c|c|c|c|} 
& $\mathbf{C 1}$ & $\mathbf{V 1}$ & $\mathrm{P}^{6}$ & $\mathbf{V 1}$ & $\mathbf{C 2} / \mathbf{d} /$ & $\mathbf{C 3} / \mathbf{s} /$ & $\mathbf{V 2}$ & $/ \mathbf{d s} /$ \\
\hline SI & 77 & 100 & 44 & 82 & 77 & 70 & 47 & 147
\end{tabular}

$6 \quad ?$ points to the duration of laryngealisation. 
The role of stød seems to be quite important here. Two tones occur in Livonian primary-stressed syllables: the plain (or rising) tone and the broken tone or stød which is rising-falling (see Tuisk 2015 for details) ${ }^{7}$. Livonian stød can be defined as a phonological unit, which on the suprasegmental level has particular characteristic features. The most typical aspect is a specific shape of the pitch excursion, which sometimes can be accompanied by laryngealisation, i.e., irregular vibrations of the vocal folds. The change in the phonation pattern may refer to the change of the syllable boundary location, i.e., from the middle to the front of the sequences.

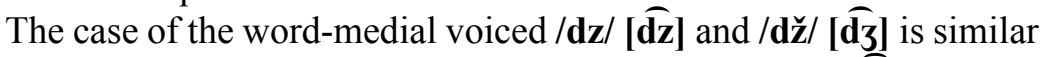
to that of the voiceless affricates /ts/ and /tšs/. Voiced /dz/ [dz $]$ and /dž/

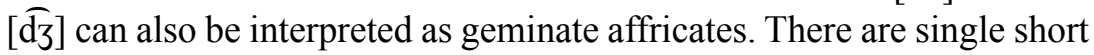
voiced geminate affricates as well as long voiced geminate affricates in Livonian. Both geminate affricates can be part of consonant clusters, e.g., ä'bvoindzi 'unhappy' (est õnnetu, lv nelaimīgs), bõ 'ndžimi 'buzz' (est sumin, lv sīkšana). Again, the existence of stød supports the fact that there are short geminate affricates in such words as $t \ddot{a ̈} d z i$ [tæ:: ?dzi] 'important' (est tähtis, lv nozìmīgs, svarīgs, ievējorams) and zno'udž̃ 'to strangle' [zno?udzə] (est kägistada, lv žņaugt).

Another aspect is the transition from the voiced stop /d/ to the fricative /žl. It seems that at least in word-medial position, the transitions are smoother and less sharp than, for instance, in the case of the voiceless sequence /ts/ in Figure 3.

In the following figures and tables, the segment durations and spectrograms of the words dadž ' 'thistle' [dadza'] (est takjas, lv dadzis) and $d a^{\prime} d z \check{z} \tilde{0}\left[\mathrm{da}^{2} \mathrm{~d} z \partial\right]$ 'thistle, PSg' (est takjas, lv dadzis) are shown.

7 In the standard orthography, stød is usually left unmarked, but in transcriptions, it is marked with an apostrophe. In the current paper, a superscript glottal stop symbol [?] is used following the conventions of IPA transcription. 

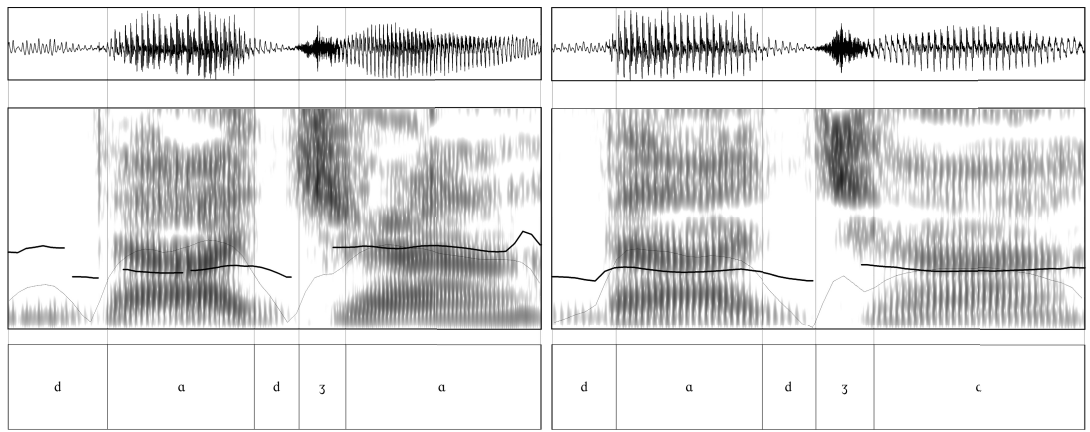

Figure 7. Spectrograms of the phrase-final (on the left) and sentence-final (on the right) test word $d a d z \bar{z} \bar{a}$ 'thistle' (pronounced by female speaker EŽ).

Table 9. Segment durations (in ms) of the word $d a d z \bar{a}$ ' thistle' (PF = phrase-final position, $\mathrm{SF}=$ sentence-final position).

\begin{tabular}{c|c|c|c|c|c|c} 
& $\mathbf{C 1}$ & $\mathbf{V 1}$ & $\mathbf{C 2} / \mathbf{d} /$ & $\mathbf{C 3} / \check{\mathbf{z}} /$ & $\mathbf{V 2}$ & $/ \mathbf{d} \check{\mathbf{z}} /$ \\
\hline $\mathbf{P F}$ & 135 & 202 & $\mathbf{6 1}$ & $\mathbf{6 4}$ & 266 & $\mathbf{1 2 5}$ \\
\hline $\mathbf{S F}$ & 76 & 173 & $\mathbf{6 5}$ & $\mathbf{6 9}$ & 250 & $\mathbf{1 3 4}$ \\
\end{tabular}

The durations of the voiced stop and the following fricative are almost the same. The overall duration of /dž/ is very similar both in phrase-final and sentence-final position. In this example, /dž/ is a short geminate affricate.

In Figure 8 and Table 10, the spectrograms and segment durations of the word $d a$ ' $d z \tilde{z} \tilde{\text { [da }} \mathrm{da}^{2} \mathrm{~d} z$ ] 'thistle, PSg' are shown. This word includes a long geminate affricate between vowels. 


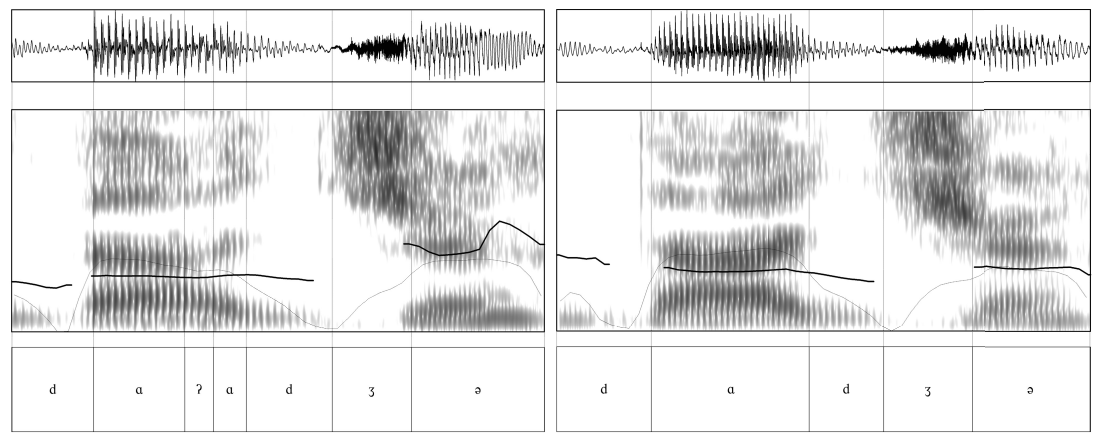

Figure 8. Spectrograms of the phrase-final (on the left) and sentence-final (on the right) test word $d a$ ' $d \check{z} \tilde{o}$ 'thistle, PSg' (pronounced by female speaker EŽ).

Table 10. Segment durations (in ms) of the word $d a$ ' $d \check{z} \tilde{o}$ 'thistle, $\mathrm{PSg}$ ' $\left(\mathrm{PF}=\right.$ phrase-final position, $\mathrm{SF}=$ sentence-final position). ${ }^{8}$

\begin{tabular}{c|c|c|c|c|c|c|c|c|} 
& $\mathbf{C 1}$ & $\mathbf{V 1}$ & $\mathrm{P}^{8}$ & $\mathbf{V 1}$ & $\mathbf{C 2} / \mathbf{d} /$ & $\mathbf{C} 3 / \check{\mathbf{z}} /$ & $\mathbf{V 2}$ & $/ \mathbf{d z} /$ \\
\hline $\mathbf{P F}$ & 93 & 104 & 33 & 38 & $\mathbf{9 8}$ & $\mathbf{9 1}$ & 152 & $\mathbf{1 8 9}$ \\
\hline $\mathbf{S F}$ & 119 & 201 & & & $\mathbf{9 4}$ & $\mathbf{1 1 2}$ & 149 & $\mathbf{2 0 6}$ \\
\hline
\end{tabular}

There is no considerable difference in the durations of the voiced stop and fricative in the word $d a ' d z \check{o}$. The fricative in sentence-final position is slightly longer in duration, but this can be explained by the fact that the test-word was pronounced in sentence-final position. The overall longer duration for /dž/ in this word is probably due to the shorter duration of the second syllable vowel. Note that this word takes part in the quantity alternation found in Livonian.

\subsection{Word-final affricates}

In word-final position, the voiceless affricates $/ \mathbf{t s} /[\widehat{\mathbf{t s}}], / \mathbf{t} \breve{\mathbf{s}} /[\widehat{\mathbf{t}}]]$ and voiced affricates $/ \mathbf{d z} /[\mathbf{d} \widehat{\mathbf{z}}]$ and $/ \mathbf{d} \check{\mathbf{z}} /[\widehat{\mathbf{d} z}]$ occur in Livonian. There are word-final single affricates, e.g., pätšs 'splash' (est plärts, lv plukt) as well as affricates which are part of the consonant cluster, e.g., dant $t^{5}$ 'dance' (est tants, lv deja). The majority of the words consisting of

8 Laryngealisation was detected only in the phrase-final word. 
these affricates are nouns - either descriptive and onomatopoeic words or loanwords. Many such words are monosyllabic.

Word-final voiceless affricates $/ \mathbf{t s} /[\widehat{\mathbf{t s}}]$ and $/ \mathbf{t} \check{\mathbf{s}} /[\widehat{\mathbf{t}}]]$ are rather well represented in Livonian. Examples of such words include

kaits 'defence' (est kaitse; vaht -i, lv aizsardzība; aizsargs, sargs)

platš 'square, plaza' (est plats, lv laukums).

dutš 'dozen' (est tosin, lt ducis)

An example of the monosyllabic word mõits [muits] 'otherwise' $(\sim$ mõitiz, $\sim$ mõitõz, est muidu, lv citādi) is given in Figure 9 and the segment durations in Table 11.
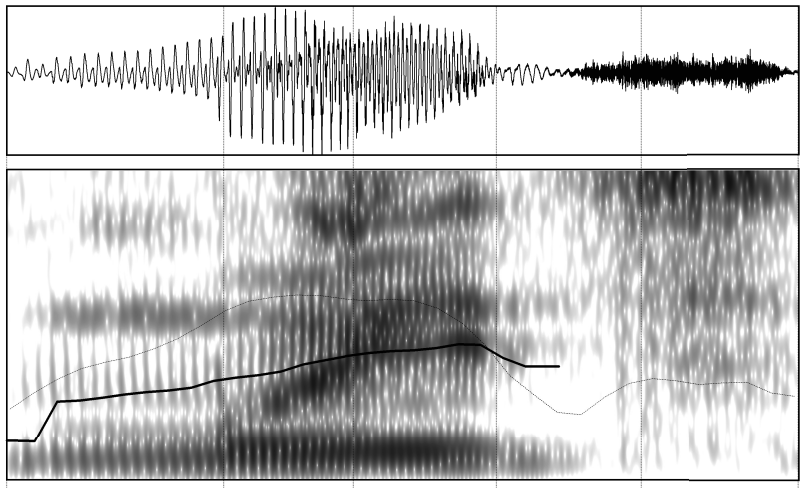

\begin{tabular}{|l|l|l|l|l|}
\hline $\mathrm{m}$ & $\mathrm{u}$ & $\mathrm{i}$ & $\mathrm{t}$ & $\mathrm{s}$ \\
\hline
\end{tabular}

Figure 9. Spectrogram of the phrase-initial test word mõits 'otherwise' (pronounced by male speaker PD).

Table 11. Segment durations (in ms) of the word mõits 'otherwise' (PI = phrase-initial position).

\begin{tabular}{c|c|c|c|c|c|c|} 
& $\mathbf{C 1}$ & $\mathrm{V} 1$ & $\mathrm{~V} 2$ & $\mathrm{C} 2 / \mathrm{t} /$ & $\mathrm{C} 3 / \mathrm{s} /$ & $/ \mathrm{ts} /$ \\
\hline PI & 121 & 73 & 80 & 81 & 88 & $\mathbf{1 6 9}$
\end{tabular}

Similar to previous examples, the duration of $/ \mathrm{t} /$ and $/ \mathrm{s} /$ are almost the same. Also, the transition from the closure to the frication is not sharpened. Figure 10 and Table 12 show the spectrogram and segment 
durations of the word Tsälmõts 'Tsälmõt, IneSg' in order to compare the word-final/ts/ sequences.

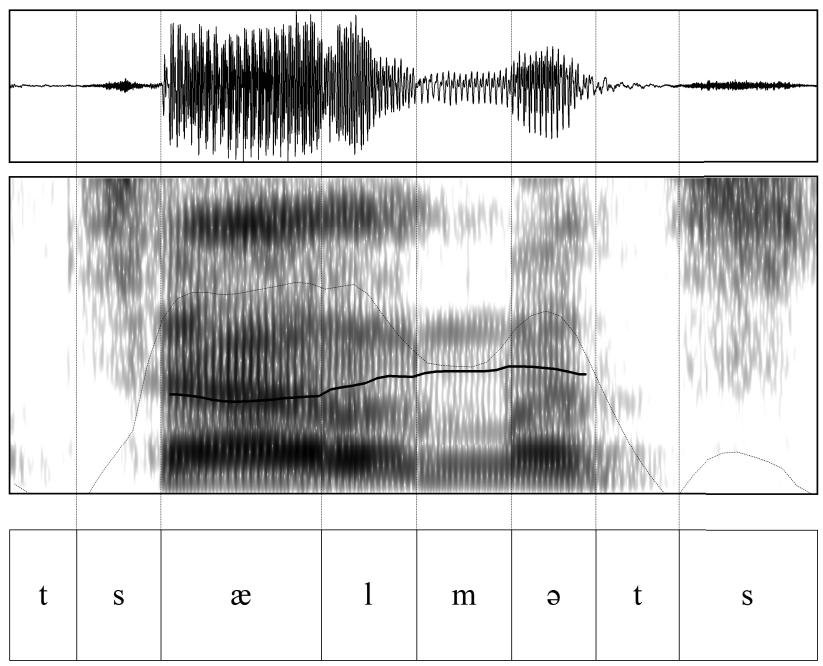

Figure 10. Spectrogram of the phrase-medial test word Tsälmõts 'Tsälmõt, IneSg' (pronounced by male speaker PD).

Table 12. Segment durations (in ms) of the word Tsälmõts 'Tsälmõt, IneSg' (PM = phrase-medial position).

\begin{tabular}{c|c|c|c|c|c|c|c|c|c|c|} 
& $\mathbf{C 1} / \mathbf{t} /$ & $\mathbf{C 2} / \mathbf{s} /$ & $/ \mathbf{t s} /$ & $\mathbf{V 1}$ & $\mathbf{C 3}$ & $\mathbf{C 3}$ & $\mathbf{V 2}$ & $\mathbf{C 4} / \mathbf{t} /$ & $\mathbf{C 5} / \mathbf{s} /$ & $/ \mathbf{t s} /$ \\
\hline $\mathbf{P M}$ & $\mathbf{6 1}$ & $\mathbf{7 6}$ & $\mathbf{1 3 7}$ & 144 & 87 & 85 & 76 & $\mathbf{7 5}$ & $\mathbf{1 2 5}$ & $\mathbf{2 0 0}$ \\
\cline { 5 - 8 }
\end{tabular}

In this example, /ts/ occurs in word-initial position and word-final position. The main difference between these two sequences is in duration of the fricative. The fricative is longer in duration in the word-final sequence $(125 \mathrm{~ms})$, while in word-initial position the stop and fricative have similar durations ( 61 and $76 \mathrm{~ms}$ ). This difference can be explained by the fact that the fricative /s/ at the end of the word morphologically marks the inessive case.

There also exist the word-final voiced affricates /dz/ [ $[\widehat{d z}]$ and /džl [d]z]. There are not many such words and much as in previous cases, these affricates appear mostly in Latvian loanwords and adverbs, e.g.,

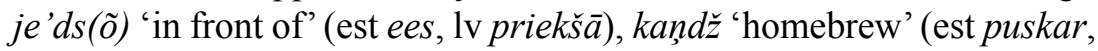
hansa, lv kandža), sprōdž 'buckle' (est nall, pannal, lv sprādze). 
To summarise the topic of Livonian affricates, it must be stated that despite the limited number of test words from only two Livonian speakers, the results of the acoustic data reveal a certain trend. The segments within the affricate are both short in duration, resulting in an overall short duration. The transition from the closure to the frication usually is smooth. In addition to the single affricates, affricates as part of consonant clusters are also present in Livonian.

\section{Conclusions}

The materials used in this article show that affricates are clearly present in Livonian. The words containing affricates in Livonian are mostly Latvian loanwords, descriptive and onomatopoeic words, but also nouns, verbs, and adverbs. The voiceless alveolar and palatal alveolar affricates /ts/ /tšs/ and voiced alveolar and palatal alveolar affricates / $\mathrm{dz} / \mathrm{dzz} /$ occur word-initially, word-medially, and word-finally. In addition, the palatalised affricate /d̦š/ is also present.

The following phonetic characteristics can be identified for Livonian affricates:

- The durations of the closure and the subsequent frication in the affricate are more or less similar.

- The durations of the closure and frication in the affricate are quite short.

- The affricate can be even shorter in duration than a single stop or fricative.

- The transition from the closure to the fricative is quite smooth in case of word-medial and word-final voiced affricates.

- Word-medial voiceless /ts/ and /tšs/ between vowels are not single consonants like Livonian voiceless plosives in the same position; they are short or long geminates or consonant clusters depending on the quantity alternation.

- The existence of the broken tone or stød must not be ignored, as the position of the syllable boundary can be changed depending on the pronunciation of the affricates.

For a more comprehensive study, a larger amount of acoustic data is probably needed and also additional word examples for inclusion in the materials. However, the existence of affricates in Livonian is certain. Their phonological descriptions are rather well supported by phonetic data. 


\title{
Acknowledgements
}

This study was supported by the institutional research funding IUT237 and the Livonian grammar and databases financed by the Estonian Ministry of Education and Research. I am very thankful to Tiit-Rein Viitso for his helpful advice and Uldis Balodis for editing the language of this paper. My deepest gratitude goes to Prof. Karl Pajusalu for his encouragement and supportive discussions.

\author{
Address: \\ Tuuli Tuisk \\ Institute of Estonian and General Linguistics \\ University of Tartu \\ Jakobi 2-409 \\ 51014 Tartu, Estonia \\ E-mail: tuuli.tuisk@ut.ee
}

\begin{abstract}
Abbreviations
AEDKL - University of Tartu Archives of Estonian Dialects and Kindred Languages, $\mathrm{C}$ - consonant, de - German, est - Estonian, Ger - gerund, IllSg - illative singular, IneSg - inessive singular, Inf infinitive, IPA - International Phonetic Alphabet, lv - Latvian, ms millisecond, PF - phrase-final position, PI - phrase-initial position, $\mathrm{PM}$ - phrase-medial position, PSg - partitive singular, SF - sentencefinal position, $\mathrm{V}-$ monophthong
\end{abstract}

\section{References}

AEDKL $=$ University of Tartu Archives of Estonian Dialects and Kindred Languages Available online at $<\mathrm{http}$ ://www.murre.ut.ee/arhiiv/>. Accessed on 05.12.2018.

Ariste, Paul (1948) Vadja keele grammatika. (Nõukogude Soome-Ugri Teadused, 9.) Tartu: RK "Teaduslik kirjandus".

Ariste, Paul (1953) Eesti keele foneetika. Tallinn: Eesti Riiklik Kirjastus.

Damberg, Pētõr (1978a) "Liivi keelekorraldusest". Emakeele Seltsi aastaraamat 23, 71-82.

Damberg, Pētõr (1978b) “Līvõ kīel kõrdõlpanmi”. Emakeele Seltsi aastaraamat 23, 83-92. 
Hint, Mati (1965) "Murrakute foneetiliste ja fonoloogiliste süsteemide kirjeldamisest". Emakeele Seltsi aastaraamat 11, 113-156.

Hint, Mati (1998) Häälikutest sõnadeni: eesti keele häälikusüsteem üldkeeleteaduslikul taustal. Tallinn: Eesti Keele Instituut.

Kallio, Petri (2007) "Kantasuomen konsonanttihistoriaa”. In Jussi Ylikoski and Ante Aikio, eds. Sámit, sánit, sátnehámit: Riepmočála Pekka Sammallahtii miessemánu 21. beaivve 2007, 229-249. (Mémoires de la Société Finno-Ougrienne, 253.) Helsinki: Suomalais-Ugrilainen Seura.

Kallio, Petri (2016) "Historical phonology from Proto-Finnic to Proto-Livonian". Journal of Estonian and Finno-Ugric Linguistics (ESUKA - JEFUL) 7, 1, 39-65.

Kettunen, Lauri (1938) Livisches Wörterbuch mit grammatischer Einleitung. (Lexica Societatis Fenno-Ugricae, 5.) Helsinki: Suomalais-Ugrilainen Seura.

Ladefoged, Peter and Ian Maddieson (1997) The sounds of the world's languages. Oxford: Blackwell Publishing.

Ladefoged, Peter, Keith Johnson (2011) A course in phonetics. 6th ed. Wadsworth: Cengage Learning.

Laua, Alise (1997) Latviešu literārās valodas fonētika. 4th red. ed. Riga: Zvaigzne ABC.

Laver, John $(1994,2008)$ Principles of phonetics. Cambridge: Cambridge University Press.

Lehiste, Ilse (1960) “An acoustic-phonetic study of internal open juncture”. Phonetica. Suppl. ad. Vol. 5, 37-38.

Lehiste, Ilse, Pire Teras, Valts Ernštreits, Pärtel Lippus, Karl Pajusalu, Tuuli Tuisk, and Tiit-Rein Viitso (2008) Livonian prosody. (Mémoires de la Société Finno-Ougrienne. 255.) Helsinki.

Lippus, Pärtel (2005) "Võru ja eesti standardkeele /ts/". Emakeele Seltsi aastaraamat $51,61-79$.

Pajusalu, Karl (2011) “Salatsi liivi keel”. In Renāta Blumberga, Tapio Mäkeläinen, and Karl Pajusalu, eds. Liivlased. Ajalugu, keel ja kultuur, 219-229. Tallinn: Eesti Keele Sihtasutus.

Posti, Lauri (1942) Grundzüge der livischen Lautgeschichte. (Mémoires de la Société Finno-Ougrienne, 85.) Helsinki.

Tarnoczy, Tamas (1987) "The formation, analysis and perception of Hungarian affricates”. In Honor of Ilse Lehiste. Ilse Lehiste pühendusteos, 255-270. (Netherlands Phonetic Archives, 6.) Dordrecht, Providence: Foris Publications.

Urek, Olga (2016) "Consonant-vowel interactions in modern standard Latvian: a representational and constraint-based account”. Glossa: a journal of general linguistics $1,1,22,1-34$.

Viitso, Tiit-Rein (1981) Läänemeresoome fonoloogia küsimusi. Tallinn: ENSV TA Keele ja Kirjanduse Instituut.

Viitso, Tiit-Rein (2001) "Historical phonology of Finnic languages: Proto-Finnic". Finnisch-Ugrische Mitteilungen 23, 1999, 197-208.

Viitso, Tiit-Rein (2007) "Livonian gradation: types and genesis". Linguistica Uralica $43,1,45-62$. 
Viitso, Tiit-Rein (2008) Liivi keel ja läänemeresoome keelemaastikud. Tartu-Tallinn: Eesti Keele Sihtasutus.

Viitso, Tiit-Rein and Valts Ernštreits (2012) Lìvõkīel-êstikiel-leţkiel sõnārōntõz. Liivieesti-läti sõnaraamat. Lībiešu-igauņu-latviešu vārdnīca. Tartu and Rīga: Tartu Ülikool and Latviešu valodas aǵentūra.

Wiedemann, Ferdinand Johann (1861) Joh. Andreas Sjögren's Livisch-deutsches und deutsch-livisches Wörterbuch. Im Auftrage der Kaiserlichen Akademie der Wissenschaften bearbeitet von Ferdinand Joh. Wiedemann. (Joh. Andreas Sjögren's Gesammelte Schriften, Bd. 2, Teil 2.) St. Petersburg.

Winkler, Eberhard and Karl Pajusalu (2018) Salis-Livisch II: Grammatik und Wörterverzeichnis. Mit einem Anhang zu den salis-livischen Sprichwörtern. (Veröffentlichungen der Societas Uralo-Altaica, 89.) Wiesbaden: Harrassowitz Verlag.

Kokkuvõte. Tuuli Tuisk: Tähelepanekuid liivi keele afrikaatide kohta. Artikli eesmärk on kirjeldada liivi keele afrikaate. Läänemeresoome keeltest on afrikaate kirjeldatud lõunaeesti, vepsa, vadja ja karjala keeles, liivi keele afrikaadid on aga suures osas seni kirjeldamata. Artiklis kasutatud foneetiline ainestik näitab, et liivi keele fonoloogilises süsteemis on olemas helitu alveolaarne afrikaat $/ \mathrm{ts} /[\widehat{\mathrm{ts}}]$, helitu palataalalveolaarne $/ \mathrm{tš} /[\widehat{\mathrm{t}}] \mathrm{ja}$ nende helilised

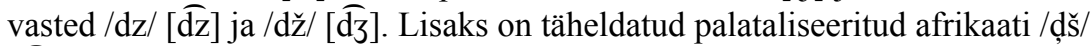
[ $\widehat{\mathrm{d}} \mathrm{j}]$. Afrikaate sisaldavad sõnad on eeskätt läti keele laensõnad, deskriptiivsed ja onomatopoeetilised sõnad. Esinevad mõned iseloomulikud akustilised tunnused, mis eristavad liivi keele afrikaate konsonantühenditest. Näiteks on afrikaadi kestus üsna lühike, olles mõnikord lühem üksikust frikatiivist. Üleminek sulult frikatiivile on afrikaatide puhul sujuvam kui vastava konsonantühendi puhul. Afrikaatide hääldamisel on oluline ka katketooni esinemine. Nimelt võib katketoon tingida häälduses silbipiiri asukoha muutuse.

Märksõnad: fonoloogia, foneetika, konsonandid, afrikaadid, läänemeresoome keeled, liivi keel

Kubbõvõttõks. Tuuli Tuisk: Tădõlpanmizt iḷ līvõ kīel afrikātõd. Kēra tuņšlõb līvõ kīel afrikātidi. Vāldamiersūomõ kēlšsti afrikātõd ātõ lieudtõb jedālēsti, vepsā, vaḍā ja karjala kīels. Siegid līvõ afrikātõd äb ūotõ nei jõvīst tuņšõltõd. Fonētili material sīes kēras nägțõb, ku līvõ kīel fonolōgij sistēms attõ seḷlizt

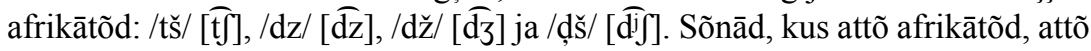
amā jemīṇ lețkīelstõ täpīṇtõd sõnād, deskriptīvizt ja onomatopoetik sõnād. Lìvõ kīel afrikātidi äb või piddõ innõzkillijid kubūdõks. Nägțõbõks afrikātõd attõ killõld lîtizt, jo lītimizt äbku īžki frikatîv. Illlämi $t$-st agā $d$-st frikatīv pälõ äb ūo nei vaimi ku innõzkillijizt kubsõ. Tä̉zi um ka līvõ kīel katkāndõks agā murdtõd tūon,. Až siedā īeldõb, zilb rubīž võib vaidõ en̦tš kūož. 